\title{
New records for the pseudoscorpion fauna of the Bakony Mts, Hungary (Arachnida: Pseudoscorpiones)
}

\author{
J. NOVÁK \\ János Novák, Eötvös Loránd University, Department of Systematic Zoology and Ecology, H-1117 Budapest, \\ Pázmány P. sétány 1/C, Hungary. E-mail: novakjanos01@gmail.com.
}

\begin{abstract}
The pseudoscorpion fauna of the Bakony Mts, Hungary is investigated. Thirteen species are recorded, seven of them new to the area. Neobisium brevidigitatum (Beier, 1928) and Withius hispanus (L. Koch, 1873) are new for the fauna of Hungary.
\end{abstract}

Keywords. Pseudoscorpions, Hungary, faunistics, new records.

\section{INTRODUCTION}

$\mathrm{T}$ he Bakony Mountains are situated at the western part of Hungary, north of Lake Balaton. In a wider sense the Balaton Uplands and the Keszthelyi Mountains also belong to the Bakony Mts, consequently these areas are also covered.

Tömösváry (1882) carried out the first faunistic study of the Bakony Mts in which he recorded Neobisium carcinoides (Hermann, 1804) (as Obisium carcinoides Hermann, 1804), Neobisium sylvaticum C. L. Koch, 1835 (as Obisium sylvaticum C. L. Koch, 1835), Roncus lubricus L. Koch, 1873, Chernes cimicoides (Fabricius, 1793), Dinocheirus panzeri C. L. Koch, 1837 (as Chernes rufeolus Simon, 1879), Chelifer cancroides (Linnaeus, 1758), Dactylochelifer latreillii Leach, 1817 (as Chelifer degeeri C. Koch, 1837), and Rhacochelifer peculiaris (L. Koch, 1873) (as Chelifer peculiaris L. Koch, 1873). Later Daday (1888) added Withius piger (Simon, 1878) (as Chelifer subruber Simon) to the species list of the region (synonymies after Harvey 2013).

During his surveys Loksa $(1960,1966)$ broadened the list with Chthonius tetrachelatus (Preyssler, 1790), Neobisium erythrodactylum (L. Koch,
1873) and Neobisium simile (L. Koch, 1873). In the 21th century Novák (2011) and Novák \& Kutasi (2014) have investigated the pseudoscorpion fauna of the Bakony Mts, and reported three species new to the area: Chthonius ressli Beier, 1956, Pselaphocernes scorpioides (Hermann, 1804) and Atemnus politus (Simon, 1878).

The aim of this paper is to contribute to our knowledge on the pseudoscorpion fauna of the region.

\section{MATERIAL AND METHODS}

Within this survey the pseudoscorpion material of the Hungarian Natural History Museum and the Bakony Museum of the Hungarian Natural History Museum were studied. The specimens were collected by sampling, sifting and using pitfall traps. Acronyms of the collectors are as the followings: AP - Attila Podlussány; CsK - Csaba Kutasi; IK - István Kovács; JW - János Wachsmann; LSz - László Szalay; LT - László Tóth; TN - Tamás Németh; VSz - Vilmos Székessy; ZKa - Zoltán Kaszab; ZKo - Zoltán Korsós.

The material was examined using stereo and compound light microscope. The specimens were 
cleared in lactic acid. Drawings were made with the aid of a Zeiss Axioskop 2 microscope. Measurements were carried out by the use of Olympus Soft Imaging analySIS work 5.0 software. The specimens are preserved in $70 \%$ ethanol and deposited at the Hungarian Natural History Museum and at the HNHM Bakony Museum. Each item is accompanied by an inventory number ('HNHM Pseud-Nr.' in case of Hungarian Natural History Museum and 'NHMB Pseud-Nr.' in case of HNHM Bakony Museum).

\section{RESULTS}

\section{List of species}

\section{Family Chthoniidae Daday, 1888}

\section{Chthonius (Ephippiochthonius) tetrachelatus (Preyssler, 1790)}

Locality. Zirc: 08.1896, JW (29 HNHM Pseud-1430).

Remarks. Chthonius tetrachelatus is a common species in Hungary (Kárpáthegyi 2007). It has been reported earlier from the area by Loksa (1966) and Novák (2011).

\section{Family Neobisiidae Chamberlin, 1930}

\section{Neobisium brevidigitatum (Beier, 1928)}

(Figures 1A-D)

Locality. Vászoly, 15.05.1941, ZKa\&VSz (10ึ, 1 + HNHM Pseud-1385).

Short description of the specimens. Carapace (Fig. 1A) as long as broad, smooth, epistome triangular, two pairs of well-developed eyes; $21-$ 22 long setae and 1-2 preocular setae on each side; setal formula: 4:6:4:7-8.

Coxal area. Manducatory process with 6 setae, pedipalpal coxa with 10-14 setae; pedal coxa I with 8-9 setae; II: 5-8; III: 6-10; IV: 10-14. Anterolateral process of coxa I long and triangular; medial process prominent, with denticles.
Opisthosoma. Chaetotaxy of tergites I-X: 8:10:10:11:12:11:11:10:11:10. Tergite XI with 10 setae, 4 of them tactile. Anal cone with $2+2$ setae. Chaetotaxy of sternites IV-X: 16:16:13:14:15: 14:12. Female genital area: sternite II with 17 small setae, sternite III with 15 small setae in a row. Male ophistosomal characters could not be investigated in detail due to their poor condition.

Chelicera (Fig. 1B). Hand with 7 setae; female spinneret flattened, male prominent and rounded; fixed finger with 10-13 small teeth, movable with 6-8 teeth.

Pedipalp (Fig. 1C). Surface smooth, trochanter with one button-like tubercle on antiaxial face; femur 3.32-3.67, patella 2.02-2.33 times as long as broad. One tubercle on antiaxial face of femur; fixed chelal fingers with 50-55 close-set teeth of equal length; movable chelal finger with 46-50 flattened teeth; trichobothria as in Fig. 1D; distance between trichobothria $i b$ and ist twice that between ist and it.

Measurements (in $\mathrm{mm}$ ) and ratios. Body length 2.72. Carapace 0.81-0.92/0.91. Chelicera $0.53 / 0.31$; movable finger 0.31 . Palpal femur $1.02-1.11 / 0.31(3.32-3.67 \mathrm{x})$, patella $0.73 / 0.31-$ $0.35(2.02-2.33 \mathrm{x})$, hand $0.75-0.81$, pedicel 0.08 0.11 , finger 1.02 .

Remarks. This is a new species for the fauna of Hungary. It was previously reported from Georgia, Poland, Slovakia, and from Romania (Harvey 2013).

\section{Neobisium carcinoides (Hermann, 1804)}

Localities. Bakonybél, 07.04.1898, JW (10ْ: HNHM Pseud-1373); Balatonhenye, Lake Monostori, sifting, 10.04.2012, CsK, (1우 NHMB Pseud-0003); Réde, acacia grove, pitfall trap, 26.05.2011-08.07.2011, CsK (1ð NHMB Pseud0011); Tés, 04.04.2012, TN\&CsK (1 ڤ̊ NHMB Pseud-0025); Zirc, Bocskor Hill, 21.10.1941 LSz\&IK (2今, 3 + HNHM Pseud-1400); Pintér Hill, sifting, 17.10.1941, LSz\&IK (10̂, 3 ㅇ

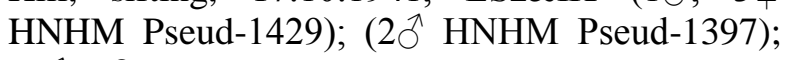
(1ठ, 2 ㅇ HNHM Pseud-1398). 


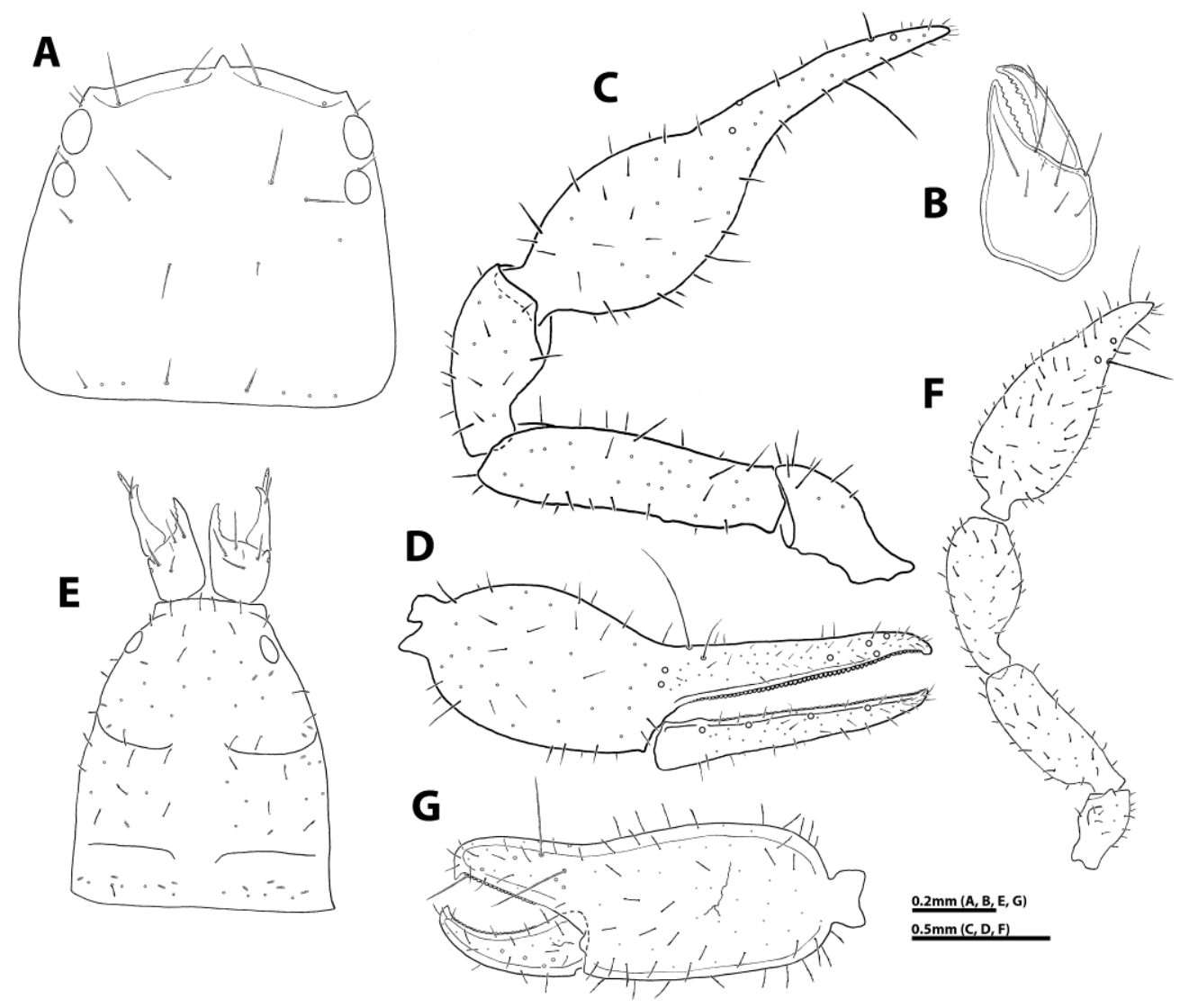

Figure 1. Neobisium brevidigitatum $\mathrm{Q}: \mathrm{A}=$ carapace, $\mathrm{B}=$ right chelicera, $\mathrm{C}=$ left pedipalp, dorsal view; $\mathrm{D}=$ right chela, lateral view; Withius hispanus: $\mathrm{E}=$ carapace and chelicerae, $\mathrm{F}=$ left pedipalp, $\mathrm{G}=$ left chela, lateral view.

Remarks. The species is widespread across Hungary, and it was already known from the area before the present study (Tömösváry 1882, Loksa 1960, Novák 2011).

\section{Neobisium sylvaticum (C. L. Koch, 1835)}

Localities. Bakonybél, 07.04.1898, JW (5 ad.: HNHM Pseud-1372); Balatonkenese, Soós Hill, pitfall trap, 03.04.2012, CsK (1§ NHMB Pseud0007); Soós Hill, loess steppe, pitfall trap, 03.04.2012-26.04.2012, CsK (6今, 7우 NHMB Pseud-0013); 29.09.2011-11.11.2011, CsK (6⿳亠丷, 69 NHMB Pseud-0014); Eplény, Malom Valley, sifting, 26.11.2006, CsK (1ㅇ NHMB Pseud0021); Farkasgyepü, 'old Fagetum wood', pitfall trap, 09.12.1975-19.04.1976, LT (6 ad. HNHM Pseud - 1370); Hárskút, Rák-tanya, 01.07.2007,
CsK (1へ̂, 2 ㅇ NHMB Pseud-0039); Hegymagas, 03.11.2006. CsK (1ð NHMB Pseud-0018); Réde, false acacia grove, pitfall trap, 18.08.2011-23.09. 2011, CsK (1우 NHMB Pseud-0024); Vászoly, 15.05.1941, ZKa\&ISz (1 + HNHM Pseud-1386); Zirc, Arboretum, pitfall trap, 12.01.200529.03.2005, CsK (1ㅇ NHMB Pseud-0017); Arboretum, sifting, 14.04.2006, AP\&CsK (1ㅇ NHMB Pseud-0028); Bocskor Hill, 21.10.1941 LSz\&IK (1ㅇ HNHM Pseud-1381); (2q HNHM Pseud1401); Pintér Hill, 18.10.1941, LSz\&IK (1ठ HNHM Pseud-1383); 17.10.1941, LSz\&IK (1ㅇ HNHM Pseud-1384); (1ㅇ HNHM Pseud-1399).

Remarks. Common species in Hungary. $N$. sylvaticum was reported from the Bakony Mts before (Tömösváry 1882, Loksa 1966, Novák 2011). 
Family Cheiridiidae Hansen, 1894

Cheiridium museorum (Leach, 1817)

Locality. Zirc, Deák Ferenc Street No39, from house, 07.03.2012, CsK (1우 NHMB Pseud0004).

Remarks. New species for the fauna of the Bakony Mts.

\section{Family Cheliferidae Risso, 1826}

Dactylochelifer latreillii (Leach, 1817)

Locality. Vászoly, 15.05.1941, ZKa\&ISz (1q HNHM Pseud-1387).

Remarks. Tömösváry (1882) has reported yet this species from that area.

\section{Family Chernetidae Menge, 1855}

\section{Allochernes peregrinus Lohmander, 1939}

Locality. Tihany, 15.05.1941, ZKa\&VSz (19, 2 juv. HNHM Pseud-1380).

Remarks. New for the region. After the Hortobágy National Park (Mahnert 1983) the Bakony Mts is the second occurrence of the species in Hungary.

\section{Chernes cimicoides (Fabricius, 1793)}

Locality. Bakonybél, 07.04.1898, JW (2ㅇ HNHM Pseud-1375).

Remarks. The species has data from several localities from Hungary (Kárpáthegyi 2007), and it was reported from the Bakony Mts by Tömösváry (1882).

\section{Chernes montigenus (Simon, 1879)}

Locality. Réde, acacia grove, pitfall trap, 26. 05.2011-08.07.2011, CsK (1: NHMB Pseud0010).
Remarks. New for the area. This is the third known locality of the species in Hungary (Kárpáthegyi 2007).

\section{Chernes similis (Beier, 1932)}

Locality. Tihany, 15.05.1941, ZKa\&VSz (2ð, 1 ㅇ HNHM Pseud-1379).

Remarks. New for the fauna of the Bakony Mts. The species was known so far only from the Bükk Mts in Hungary (Novák 2012).

\section{Lamprochernes chyzeri (Tömösváry, 1882)}

Localities. Noszlop, Széki Forest, oak-hornbeam (Quercus sp., Carpinus betulus) forest, 25.09.1999, ZKo (1 $\widehat{\jmath}$ HNHM Pseud-1393).

Remarks. In Hungary the species was known so far only from the Somogy Hills (Tömösváry 1882) and the Csepel Island (Novák 2013), thus the Bakony Mts is its third occurrence in the country.

\section{Pselaphochernes scorpioides (Hermann, 1804)}

Locality. Zánka, Pál Hill, under bark of the trees, 19.04.2011, CsK (1옹 NHMB Pseud-0006).

Remarks. P. scorpioides has numerous occurrences in Hungary (Kárpáthegyi 2007, Novák 2013). The species was reported from the Bakony Mts. by Novák (2011).

\section{Family Withiidae Chamberlin, 1931}

Withius hispanus (L. Koch, 1873)

$$
\text { (Figures 1E-G) }
$$

Locality. Berhida, loess steppe, 07.2013. CsK (1요: NHMB Pseud-0084).

Remarks. The species is reported from Austria, Azerbaijan, Bosnia-Herzegovina, Bulgaria, France, Georgia, Italy, Montenegro, Morocco, Portugal, Russia, Spain, Switzerland, Turkey (Harvey 2013), and recently has been reported from the 
neighbouring Slovakia as well (Christophoryová et al. 2012).

Short description of the new female specimen. Carapace (Fig. 1E) reddish brown, granulate, with two transverse furrows and a pair of eyes with lens; 52 clavate setae, 6 of them at the anterior and 9 at the posterior margin; 12 slit-like lyrifissures, 8 of which occur along the posterior margin.

Coxal area. Setae acuminate; manducatory process with 2 long and 3 short setae, pedipalpal coxa with 11-13 setae; pedal coxa I with 5-6 setae; II: 5; III: 5-6; IV: 11-16.

Opisthosoma. Tergites granulate. Tergite I partly divided, II-X divided, XI undivided; tergal chaetotaxy tergites I-X (right+left hemitergite): 6+5: 5+4: 6+6: 7+8:7+8: 6+7: 8+8: 8+8:7+7: $6+5$, tergite XI with 9 setae, 4 of them tactile. Lyrifissures on tergites I-X (right+left hemitergite): $2+2: 3+3: 3+2: 4+4: 3+4: 4+2: 3+4: 3+3$ : $3+4: 3+4$, tergite XI with 2 lyrifissures. Anal cone with $2+2$ dorsal setae. Sternite II partly divided, III-X divided, XI undivided. Sternite II with 18 setae; sternites III-IX (right+eft hemisternite): 5+4: 5+5: 7+8:7+8: 7+8: 7+7: 8+8: $6+6$; sternite XI with 12 setae, 2 of them tactile. Genital structure agrees with descriptions of Heurtault (1971) and Christophoryová et al. (2012).

Chelicera (Fig. 1E). With 5 setae on hand and one seta on movable finger; fixed and movable fingers with small and non-sclerotized teeth; rallum with 4 blades, serrula exterior with 18 blades; galea with 5 terminal rami.

Pedipalp (Fig. 1F). Palps robust, surface granulate, with clavate setae; chelal hand subcylindrical, movable finger as long as the width of the hand; fixed finger with 19 contiguous teeth, movable finger with 22; trichobotria as in Figure 1G: it dorsal, ist internal. Pedal tarsus IV bearing a long tactile seta distal to the middle of the article.

Measurements (in $\mathrm{mm}$ ) and ratios. Body length 3.32; carapace $0.73 / 0.68$ (1.06x); chelicera $0.23 / 0.13$; movable finger 0.17 ; galea length 0.06 . Pedipalp: trochanter $0.31 / 0.18(1.68 \mathrm{x})$, femur $0.60 / 0.22(2.74 x)$, patella $0.59 / 0.27(2.22 x)$, chela with pedicel $0.97 / 0.34(2.87 \mathrm{x})$, pedicel 0.08 , movable finger length 0.35 .

\section{DISCUSSION}

During the course of the study 13 pseudoscorpion species belonging to six families were found in the area of the Bakony Mts, seven of which (Neobisium brevidigitatum, Cheiridium museorum, Allochernes peregrinus, Chernes montigenus, C. similis, Lamprochernes chyzeri, Withius hispanus) are new for the region, furthermore, Neobisium brevidigitatum and Withius hispanus are new for the fauna of Hungary. Consequently, the number of pseudoscorpion species known from the Bakony Mts is increased to 22 (Tömösváry 1882, Daday 1888, Loksa 1960, 1966, Novák 2011, Novák\&Kutasi 2014).

The main taxonomic characters of Neobisium brevidigitatum and Withius hispanus correspond to the literature (Beier 1963, Christophoryová et al. 2012). However, in the case of $N$. brevidigitatum, a larger variability at the morphometric ratios of femur and tibia was documented. The $W$. hispanus female specimen shows minor differences in the number of carapace setae and slit-like lyrifissures compared to the description of Christophoryová et al. (2012).

With respect to our present knowledge regarding to the fauna of Hungary, the occurrence of further species are expected in the Bakony Mts [Chthonius (Chthonius) ischnocheles (Hermann, 1804); Chthonius (Ephippiochthonius) tuberculatus Hadzi, 1937; Neobisium validum (L. Koch, 1873); Neobisium macrodactylum (Daday, 1888); Larca lata (Hansen, 1884) and Dendrochernes cyrneus (L. Koch, 1873.

However, the pseudoscorpion fauna of large areas still remained understudied in Hungary, which indicates the necessity of further investigations on this group in the country.

Acknowledgements - I would like to thank all collectors of the examined material. The author is also grateful to Dr. László Dányi for making accessible the pseudoscorpion 
material of the HNHM, and to Dr. Csaba Kutasi for allowing the access the pseudoscorpion material of the Bakony Museum of the HNHM. I am especially grateful to Dr. Gerald Legg for his linguistic help and his comments. The manuscript was improved by the comments of Dr. Giulio Gardini and the anonymous referees.

\section{REFERENCES}

BeIER, M. (1963): Ordnung Pseudoscorpionidea (Afterskorpione). Bestimmungsbücher zur Bodenfauna Europas, 1. Akademie-Verlag, Berlin, 313 pp.

Christophoryová, J., GARDINI, G., ÉNEKESOVÁ, E. (2012): Withius hispanus new for the fauna of Slovakia (Pseudoscorpiones: Withiidae). Arachnologische Mitteilungen, 44: 10-13. doi: $10.5431 /$ aramit 4403

DADAY, E. (1888): A Magyar Nemzeti Muzeum álskorpióinak áttekintése. Természetrajzi Füzetek, 11: 111-136, 165-192.

HARVEY, M.S. (2013): Pseudoscorpions of the World, version 3.0. Western Australian Museum, Perth. http://museum.wa.gov.au/catalogues-beta/pseudoscorpions (accessed 10. December 2014).

Heurtault, J. (1971): Chambre génitale, armature génitale et caractères sexuels secondaires chez quellques espèces de pseudoscorpions (Arachnides) du genre Withius. Bulletin du Muséum National d'Histoire Naturelle, (2) 42: 1037-1053

KÁRPÁTHEGYI, P. (2007): Pseudoscorpions of Hungary. Folia Historico Naturalia Musei Matraensis, 31: 81-90.
LOKSA, I. (1960): Faunistisch-systematische und ökologische Untersuchungen in der Lóczy-höhle bei Balatonfüred. Annales Universitatis Scientiarum Budapestiensis de Rolando Eötvös Nominatae: Sectio Biologica, 3: 253-266.

LOKSA, I. (1966): Die bodenzoozönologischen Verhältnisse der Flaumeichen-Buschwälder Südostmitteleuropas. Akadémiai Kiadó, Budapest, 437 pp.

MAHnERT, V. (1983): Pseudoscorpions of the Hortobágy National Park (Arachnida). In. MAHUNKA, S. (ed.) The fauna of Hortobágy National Park 2. Akadémiai Kiadó, Budapest, p. 361-363.

NovÁK, J. (2011): Adatok a Bakony álskorpió-faunájához (Arachnida: Pseudoscorpiones). Folia Musei Historico-Naturalis Bakonyiensis, 28: 67-70.

NoVÁK, J. (2012): New records of pseudoscorpions for the fauna of Bükk Mts, Northeast Hungary (Arachnida: Pseudoascorpiones). Opuscula Zoologica Budapest, 43(1): 57-65.

NovÁK, J. (2013): Adatok Magyarország álskorpiófaunkájához. Állattani közlemények, 98 (1-2): 121129.

NovÁK, J. \& KuTASI, CS. (2014): New data on the Pseudoscorpion fauna of the caves of the Bakony Mountains, Hungary. Opuscula Zoologica Budapest, 45(2):189-194.

TÖMÖSVÁRY, Ö. (1882): A Magyar fauna álskorpiói. Magyar Tudományos Akadémia Matematikai és Természettudományi Közlemények, 18: 135-256. 